\title{
Nursery Method for Damping - off Disease in True Seed Cultivation of Cluster Onion
}

\author{
M.S.W. Fernando', S.H.S.A. De Silva ${ }^{2}$ \\ ${ }^{1}$ Horticultural Crops Research and Development Institute, Gannoruwa, Sri Lanka \\ Email: sobashinifernando@gmail.com \\ ${ }^{2}$ Director, Natural Resource Management Center, Peradeniya, Sri Lanka \\ Email: ajandes@gmail.com
}

\begin{abstract}
Onion (Allium cepa L.) is an important cash crop grown in Sri Lanka. Cluster onion cultivation in Sri Lanka is mainly grown using mother bulbs as planting material. With the introduction of true seed technology, the costs of planting material can be reduced. In general, when using seeds, the plants must be raised in a nursery for 28 days before they can be planted in a field. However, there is a gap in nursery techniques when using seeds and while expanding onion cultivations using true seed. This is a negative factor in the expansion of seed technology for agro-industrial areas such as Jaffna, Kalpitiya, Sri Lanka, since they do continues cultivation in theirfarm land. Therefore, it is required to maintain an indoor nursery if the onion is expected raise from seeds. Two soil-borne diseases that cause true seed culture in Cluster onions are damping-off (caused by Fusarium spp., Pythium spp., and Rhizoctonia solani) and Fusarium basal rot. These are the main constraint to popularizing the true seed crop. Main objective of this study was to identify the best management method for nurseries to achieve a low incidence of damping - off disease, which will help to obtain a high number of healthy stands. The sterilized normal nursery soil mix used in nursery trays in the shade showed a significantly $(p<0.05)$ lowest postemergence damping - off disease incidences. To avoid the development of an undesirable microclimate, it is essential to use nursery trays with separate holes.
\end{abstract}

Keywords - Cluster onion, Damping - off, Nursery trays, True seed cultivation.

\section{INTRODUCTION}

Onion is an important component in Sri Lankan diet. There are two main types of onions: big onion and cluster onion cultivated in Sri Lanka. Big onion cultivation is mainly done with true seeds and cluster onion can be cultivated with mother bulbs as a vegetative cultivation or using true seeds. In the seed crop, the plants must be grown in a nursery for 28 days prior for planting in a field. Current normal practice is to maintain a nursery in a nursery bed in open field. In this situation, transplanting is necessary in field establishments. Transplants are an excellent way to plant onions as healthy and vigorous transplants results in a successful culture. Cook has shown that maintaining root health is a critical condition for achieving high yields in crops (Cook, 1986). Onion seedlings are very susceptible to seedling diseases and need to be protected. The cultivation of the onion is obtained by different methods according to the conditions of the farmers. Some methods involve transplanting, sowing seeds directly and planting bulbs in the fields.

Damping - off is a serious fungal disease caused at the nursery stage. Damping off is caused by Fusarium spp. (Lewis J.A., 1977) (Szczech, 1999) Pythium spp. (McKellar \& Nelson, 2003) (Veeken et al., 2005) and Rhizoctonia solani (Papavizas G.C., 1960) (Diab, Hu, \& Benson, 2003). Fusarium spp can cause pre- and postemergence damping-off and Pythium spp. and Rhizoctonia solani have similar symptoms in young seedlings. Both Pythium spp. and Rhizoctonia solani kill seedlings from the inside, growing through plant tissues and destroying cells and cell walls. This leads to the collapse of the plants or 'Damping - off'. Seeding approaches too much and excess moisture in the soil can cause this disease. With excess moisture, Pythium spp. also, the favor with spore swimming will increase the level of the disease. This disease can spread quickly from one plant to another with these conditions. To prevent this disease, cultural practices such as sanitation in the field, sterilization of the soil, use of healthy seeds can be used.

As stated in the recommendation of the Sri Lankan Department of Agriculture, most soil pathogens can be removed by burning of soil or solarizing nursery beds. In addition, if the causative fungus is unknown, broadspectrum fungicides such as Captan and Thiram may be used [Anon. 2015].

To date, few studies have been conducted on the different nursery methods of other vegetable seeds and big onion seeds in Sri Lanka. Therefore, this study was conducted to determine the best management method in the nursery to achieve a low incidence of Damping - off disease, 
which will help achieve a high number of healthy stands in the true seed cultivation in cluster onion. Nine different nursery methods were tested.

\section{METHOD}

Nine treatments (Table 1) were tested in this research as follows.

Table 1: Different nursery techniques as treatments

\begin{tabular}{|c|c|}
\hline & Treatments \\
\hline $\mathrm{T} 1$ & $\begin{array}{l}\text { Neem leaves as mulch material (Sterilized } \\
\text { soil) }\end{array}$ \\
\hline $\mathrm{T} 2$ & $\begin{array}{l}\text { Seed treatment with Captan } 50 \% \text { WP } \\
(5 \mathrm{~g} / 1 \mathrm{~kg})(\text { Sterilized soil })\end{array}$ \\
\hline $\mathrm{T} 3$ & $\begin{array}{l}\text { Straw mulch and rain protection in } \\
\text { polythene (Sterilized soil) }\end{array}$ \\
\hline $\mathrm{T} 4$ & $\begin{array}{l}\text { Sterilized normal nursery soil mixture in } \\
\text { nursery trays under shade. ( } 105 \text { holes/tray) }\end{array}$ \\
\hline $\mathrm{T} 5$ & $\begin{array}{l}\text { Dapog mixture (in rice) in nursery trays in } \\
\text { the shade ( } 105 \text { holes/tray) (Sterilized soil) }\end{array}$ \\
\hline T6 & $\begin{array}{l}\text { Straw mulch and coconut leaves as a shade } \\
\text { (Sterilized soil) }\end{array}$ \\
\hline $\mathrm{T} 7$ & Straw as a mulch material (Sterilized soil) \\
\hline $\mathrm{T} 8$ & Control (Without mulch or rain cover) \\
\hline T9 & $\begin{array}{l}\text { Dapog mixture (in rice) in nursery trays in } \\
\text { the shade (without holes in the tray) } \\
\text { (Sterilized soil) }\end{array}$ \\
\hline
\end{tabular}

To test the true seed cultivation of cluster onion; seeds of Vethalam variety was used in these treatments as well as plots of $3 \mathrm{~m} * 1 \mathrm{~m}$ in the form of Random Complete Block Design (RCBD) with three replicates. Neem leaves, straw used as mulch material and polyethylene, coconut leaves and plant shade used as shading material. Captan 50\% WP Fungicide was used as a seed treatment [6]. Soil sterilization was performed by burning the paddy husk and straw in sandwich manner. All of these treatments have been developed with the experience of farmers to select the best method of nursery management. The data were analyzed statistically using SAS version 9.1.3 by the CATMOD procedure.

\section{RESULTS}

Table 2: Damping off incidences and plant stand count of onion during $1^{\text {st }}$ season

\begin{tabular}{|c|c|c|c|}
\hline \multirow[t]{3}{*}{ Treatments } & \multicolumn{3}{|c|}{ Damping off (DI \%) } \\
\hline & WAS & WAS & WAS 3 \\
\hline & 1 & 2 & \\
\hline $\begin{array}{l}\text { Neem leaves as mulch } \\
\text { material (Sterilized soil) }\end{array}$ & $\begin{array}{c}4.00 \\
\mathrm{ab}\end{array}$ & $\begin{array}{c}5.00 \\
\mathrm{ab}\end{array}$ & $5.33^{b}$ \\
\hline $\begin{array}{l}\text { Seed treatment with } \\
\text { Captan } 50 \% \text { WP }(5 \mathrm{~g} / 1 \mathrm{~kg}) \\
\text { (Sterilized soil) }\end{array}$ & $4.66^{\mathrm{a}}$ & $6.33^{a}$ & $7.00^{\mathrm{a}}$ \\
\hline
\end{tabular}

Straw mulch and rain protection in polythene (Sterilized soil)

Sterilized normal nursery soil mixture in nursery trays under shade. (105 holes/tray)

Dapog mixture (in rice) in nursery trays in the shade (105 holes/tray) (Sterilized soil)

Straw mulch and coconut leaves as a shade (Sterilized soil)

Straw as a mulch material $4.66^{\mathrm{a}} \quad 2.33^{\mathrm{c}} \quad 5.33^{\mathrm{b}}$ (Sterilized soil)

Control (Without mulch or $\quad 5.66^{\mathrm{a}} \quad 3.66 \quad 3.66^{\mathrm{d}}$ rain cover)

Dapog mixture (in rice) in nursery trays in the shade $4.33 \quad 6.66^{\mathrm{a}} \quad 9.66^{\mathrm{a}}$ (without holes in the tray) (Sterilized soil)

Table.3: Damping off incidences and plant stand count of onion during $2^{\text {nd }}$ season

\begin{tabular}{lcccc}
\hline \multicolumn{5}{c}{ Damping off (DI \%) } \\
Treatments & WAS & WAS & WAS \\
& 1 & 2 & 3 \\
\hline $\begin{array}{l}\text { Neem leaves as mulch } \\
\text { material (Sterilized soil) }\end{array}$ & & & \\
Seed treatment with Captan & $3.66^{\mathrm{b}}$ & $2.66^{\mathrm{c}}$ & $1.66^{\mathrm{b}}$ \\
$50 \%$ WP (5g/1kg) (Sterilized & ab & bc & ab \\
soil) & & & \\
Straw mulch and rain & $2.33^{\mathrm{b}}$ & $2.66^{\mathrm{c}}$ & $5.66^{\mathrm{a}}$ \\
protection in polythene \\
(Sterilized soil)
\end{tabular}




\begin{tabular}{|c|c|c|c|}
\hline $\begin{array}{l}\text { Straw mulch and coconut } \\
\text { leaves as a shade (Sterilized } \\
\text { soil) }\end{array}$ & $\begin{array}{c}3.00 \\
\mathrm{ab}\end{array}$ & $3.00^{\mathrm{c}}$ & $\begin{array}{c}3.66 \\
\mathrm{ab}\end{array}$ \\
\hline $\begin{array}{l}\text { Straw as a mulch material } \\
\text { (Sterilized soil) }\end{array}$ & $2.00^{b}$ & $\begin{array}{c}4.33 \\
\mathrm{bc}\end{array}$ & $\begin{array}{c}3.33 \\
\mathrm{ab}\end{array}$ \\
\hline $\begin{array}{l}\text { Control (Without mulch or } \\
\text { rain cover) }\end{array}$ & $5.00^{\mathrm{a}}$ & $7.00^{\mathrm{a}}$ & $\begin{array}{c}4.33 \\
\mathrm{ab}\end{array}$ \\
\hline $\begin{array}{l}\text { Dapog mixture (in rice) in } \\
\text { nursery trays in the shade } \\
\text { (without holes in the tray) } \\
\text { (Sterilized soil) }\end{array}$ & $\begin{array}{c}3.00 \\
\mathrm{ab}\end{array}$ & $6.00^{\mathrm{a}}$ & $\begin{array}{c}4.00 \\
\text { ab }\end{array}$ \\
\hline
\end{tabular}

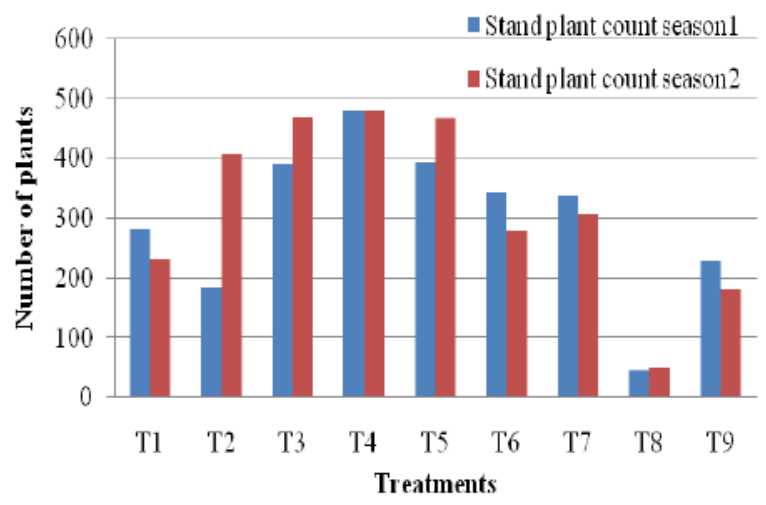

Stand plant count in two different seasons

Fig 1: Stand plant counts in two different seasons. The blue color indicates stand plant count of the season 1 and red color indicates stand plant count of the season 2.

\section{DISCUSSION}

Among the different nursery methods which were tested in this research, the control showed the highest disease incidences with the lowest plant count in both seasons. It gives an idea about that without mulch and rain cover the fungal disease can be increased. It was observed that the effect of the eight different nursery methods on this research was significant with a $\mathrm{P}<0.05$.

There is a significant in T5 and T9 treatments with the stand plant count. The major difference among them was the tray holes. These trays without holes may have facilitated the favorable micro climate in $\mathrm{T} 9$ treatment for pathogen growth. Because; it was as a blanket of dapog mixture without separating as holes compared to T5. Stand plant count in season 1 and 2 respectively 392, 466 in T5 and in T9 it was 227 and 182.

The current recommendation in $\mathrm{T} 2$ showed comparatively low plant count in season 1 and it was almost doubled in season 2. Stand plant count in season 1 and 2 were 183 and 406 correspondingly. T6 and T7 had almost similar behavior in both seasons. T6 had 343 and 277 plant stand in respective seasons whereas $\mathrm{T} 7$ had 336 and 305 in those seasons.

Our hypothesis was that the neem leaves in-cooperation in to soil will reduce the fungal diseases. Interestingly we found that the neem leaves (Fig: 1, T1) had lowered the plant counts in both seasons, 282 and 232 in respective seasons.

Among the tested treatments Fig. 1 showed that the significantly $(\mathrm{p}<0.05)$ highest number of plants in three treatments (T3), (T4) and (T5) during both seasons. Among them, the sterilized normal nursery soil mix used in nursery trays in the shade (T5) shows the lowest incidence of post- emergence damping-off with number of plant stands highest.

Table 2 and 3 showed the means of disease incidence percentages during the research. According to the data T3, T4 and T5 had the lowest damping - off disease incidences, making these methods the most effective nursery methods for the damping- off disease. In relevant seasons T3 had 390 and 468, T4 had 478 and 479 and T5 had 392 and 466 plant counts. Among them, the sterilized normal nursery soil mix used nursery trays in the shade (T5) significantly ( $\mathrm{p}<0.05)$ shows the lowest incidence of post- emergence damping-off with highest number of plants.

Due to the use of nursery trays, transplant shock with damage to the root will be zero. But the initial cost with the purchase of trays can be little high. But nurseries on trays can be grown in parallel with the previous season's crop and may not require large fields. It can also be managed in small areas.

\section{CONCLUSION}

The results of the experiments revealed that it was possible to obtain a higher number of plant stand in the three treatments (T3), (T4) and (T5) during both seasons. Among them, the sterilized normal nursery soil mix used nursery trays in the shade (T5) significantly $(\mathrm{p}<0.05)$ shows the lowest incidence of post-emergence dampingoff with highest number of plants. Based on the results, it can be concluded that the best treatment was the sterilized mixture of normal nursery soil in nursery trays. To avoid the development of an undesirable microclimate, it is essential to use nursery trays with separate holes.

\section{ACKNOWLEDGMENT}

Authors wish to acknowledge the valuable guidance provided by the cluster onion crop coordinator. My heartiest gratitude for the cluster onion farmers, who exchanged their experience with me for built up this 
research. My sincere thanks go to assistants, labors and friends who engage during this research.

\section{REFERENCES}

[1] Cook, R. J. (1986). Plant Health and the Sustainability of Agriculture, with Special Reference to Disease Control by Beneficial Microorganisms. Biological Agriculture \& Horticulture, 3(2-3), 211-232. doi:10.1080/01448765.1986.9754472

[2] Diab, H. G., Hu, S., \& Benson, D. M. (2003). Suppression of Rhizoctonia solani on Impatiens by Enhanced Microbial Activity in Composted Swine Waste-Amended Potting Mixes. Phytopathology, 93(9),

1115-1123. doi:10.1094/PHYTO.2003.93.9.1115

[3] Lewis J.A., P. G. C. (1977). Effect of plant residues on chlamydospore germination of Fusarium root rot beans. Phytopathology, 67, 925-929.

[4] McKellar, M. E., \& Nelson, E. B. (2003). CompostInduced Suppression of <em>Pythium</em> Damping-Off Is Mediated by Fatty-AcidMetabolizing Seed-Colonizing Microbial Communities. Applied and Environmental Microbiology, $\quad 69(1), \quad 452-460$. doi:10.1128/aem.69.1.452-460.2003

[5] Papavizas G.C., D. C. B. (1960). Rhizoctonia disease of bean as affected by decomposing green plant materials and associated microfloras. Phytopathology, 50, 516-522.

[6] Anonymous. (2015). Pest management recommendations. Department of Agriculture, Sri Lanka. 39.

[7] Szczech, M. M. (1999). Suppressiveness of Vermicompost against Fusarium Wilt of Tomato. Journal of Phytopathology, 147(3), 155-161. doi:doi:10.1046/j.1439-0434.1999.147003155.x

[8] Veeken, A. H. M., Blok, W. J., Curci, F., Coenen, G. C. M., Termorshuizen, A. J., \& Hamelers, H. V. M. (2005). Improving quality of composted biowaste to enhance disease suppressiveness of compostamended, peat-based potting mixes. Soil Biology and Biochemistry, 37(11), 2131-2140. 